\begin{tabular}{|l|l|l||}
\hline \multicolumn{2}{|c|}{ PublisherInfo } \\
\hline \hline PublisherName & $:$ & BioMed Central \\
\hline \hline PublisherLocation & $:$ & London \\
\hline \hline PublisherImprintName & $:$ & BioMed Central \\
\hline \hline
\end{tabular}

\title{
Bystander suppression in an auto-immune disease model
}

\begin{tabular}{|l|l|l||}
\hline \multicolumn{2}{|c||}{ ArticleInfo } \\
\hline \hline ArticleID & $:$ & 220 \\
\hline \hline ArticleDOI & $:$ & $10.1186 /$ ar-1999-66764 \\
\hline \hline ArticleCitationID & $:$ & 66764 \\
\hline \hline ArticleSequenceNumber & $:$ & 177 \\
\hline \hline ArticleCategory & $:$ & Paper Report \\
\hline \hline ArticleFirstPage & $:$ & 1 \\
\hline \hline ArticleLastPage & $:$ & 3 \\
\hline \hline & $:$ & RegistrationDate : 1999-12-15 \\
ArticleHistory & $:$ & OnlineDate $:$ 1999-12-15 \\
\hline \hline ArticleCopyright & $:$ & Current Science Ltd1999 \\
\hline \hline ArticleGrants & $:$ & \\
\hline \hline ArticleContext & $:$ & 130753311 \\
\hline \hline
\end{tabular}


Aff1 School of Medical Sciences, Bristol, UK

\section{Keywords}

\section{Context}

Autoreactive regulatory $\mathrm{T}$ cells, which are capable of preventing autoimmune disease, have been described in several animal models. If the specificity of the regulatory lymphocytes differs from that of the autoaggressive lymphocytes, the phenomenon has been termed bystander suppression. This paper investigates the mechanism of bystander suppression using a murine model of type 1 diabetes. These mice express the transgene encoding the nucleoprotein (NP) of lymphocytic choriomeningitis virus (LCMV) under the control of the rat insulin promoter (RIP). The NP is therefore selectively expressed in the ? cells of the pancreatic islets of Langerhans, and infection of these mice with LCMV results in progressive destruction of ? islet cells, leading to overt type 1 diabetes. The authors have previously shown that oral insulin can prevent diabetes in these mice. Here they demonstrate the presence of insulin-specific regulatory $\mathrm{T}$ cells. These cells locally suppress the destructive $\mathrm{T}$ cell responses directed against the viral NP, which is expressed from the transgene on ? islet cells. This regulatory mechanism was dependent on the secretion of IL-4 and on the presence of the IL-4 signalling component, stat6. To characterize regulatory autoreactive $\mathrm{T}$ cells and to investigate a potential mechanism of bystander suppression.

\section{Significant findings}

Lymphocyte cultures were established from the lymph nodes draining the pancreas of protected or diabetic mice treated with oral insulin (and non-fed controls). Only T cells from protected mice survived in vitro; these were homozygous TCRa?CD4 ${ }^{+} \mathrm{T}$ cells. Adoptive transfer of these $\mathrm{T}$ cells into prediabetic RIP-NP mice led to complete protection from diabetes.

Stimulation of the protective regulatory T cells resulted in IL-4, IL-10 and IFNa production, whereas TNF-a and IFNa were increased in non-protective T cells. RIP-NP transgenic mice, which were deficient in either IL-4 or a component of the IL-4 signalling cascade, stat6, developed diabetes normally but were not protected by oral insulin feeding. The kinetics of virus clearance and the generation of LCMV-specific cytotoxic T lymphocytes were unchanged by deficiency of either IL-4 or 
stat6. However, the RIP-NP transgenic mice which had been protected by insulin feeding did not have detectable NP-specific T cells in the pancreas. This indicates that local immune regulation is occurring with minimal or no disturbance of the systemic immune regulation. In order to test whether regulatory T-cell cytokines modulate APC function, cultures of LCMV-specific effectors were stimulated with APCs plus LCMV in the presence or absence of IL-4 or IL-12 (control). Addition of IL-4 to cultures reduced expansion and LCMV-specific cytolytic activity. Using stat6-deficient T cells cultured with wild type APCs the authors showed IL-4 acted predominantly on APCs.

\section{Comments}

This interesting paper is one of the first to clearly demonstrate bystander suppression using two distinct defined self-antigens. The authors clearly make a case for targeted immune regulation achieved by use of tissue-specific T cells. The induction of regulatory cells may overcome two basic problems that have hampered the design of immunotherapeutic regimens for organ-specific autoimmunity. Firstly, the specificity of initiating destructive lymphocytes is frequently unknown. Secondly, epitope spreading may lead to a broadening of $T$ cell autoreactivity in the target organ. The strategy described here necessitates only the manipulation of $T$ cell responses to one tissue-related autoantigen, in order to regulate the $T$ cell effector response to a myriad of other autoantigens presented locally.

\section{Methods}

The mice expressing the RIP-LCMV-NP transgene were intercrossed with either stat6-deficient or IL-4 deficient mice. The incidence of type 1 diabetes was measured following intraperitoneal administration of 105 plaque forming units of LCMV. Porcine insulin, and human, porcine or murine insulin B chains were administered orally via a feeding tube inserted into the stomach. Control groups received $1 \mathrm{mg}$ bovine serum albumin. $\mathrm{CD}^{+} \mathrm{T}$ cells were isolated from pancreatic and mesenteric lymph nodes and spleen, and cultured for successive cycles of conditioned FCS-rich medium with antigen presenting cells (APCs) pulsed with porcine insulin B chain or B chain peptides. IL-4 was added to some cultures. Flow cytometry and ELISA were used to determine cell phenotype and the profile of cytokine secretion.

\section{References}

1. Homann D, Holz A, Bot A, Coon B, Wolfe T, Petersen J, Dyrberg TP, Grusby MJ, von Herrath MG: Autoreactive $\mathrm{CD} 4{ }^{+} \mathrm{T}$ cells protect from autoimmune diabetes via bystander suppression using the IL-4/ Stat6 pathway. Immunity. 1999, 11: 463-472.

This PDF file was created after publication. 